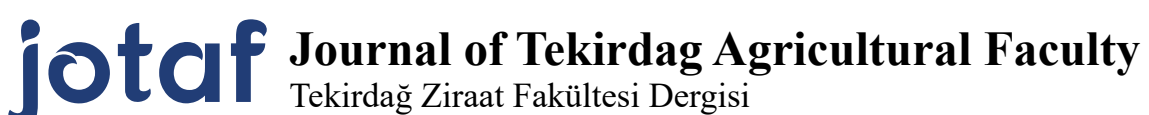

Ocak/January 2019, 16(1)

\section{Tarımsal Üretimde Kadınların Karar Alma Süreçlerine Katılımı ve Kooperatiflerden Beklentileri}

Women's Contribution to Decision Making Processes in Agricultural Production and Their Expectation From Cooperatives

\author{
Emine YILMAZ ${ }^{1 *}$, Gülen ÖZDEMIR ${ }^{1}$, Yasemin ORAMAN ${ }^{1}$, \\ Gökhan UNAKITAN ${ }^{1}$, Sema KONYALI ${ }^{1}$
}

\section{$\ddot{O} \mathbf{z}$}

Kırsal kesimde kadınların rolleri ve işlevleri oldukça önemli olmasına rağmen birçok alanda ücretsiz aile işçisi olarak çalışmaktadırlar. Kadınlar bir yandan günlük rutin ev işleri yaparken, diğer taraftan el sanatları ve tarımsal üretim gibi gelir getirici işler yaparak aile bütçesine katkı sağlamaktadır ancak aile içinde ve üretimle ilgili alınan kararlara etkin olarak katılamamaktadır. Araştırma Tekirdağ ili merkeze bağlı 55 köyde yaşayan 255 kadını kapsamaktadır. Araştırma, çeşitli yazılı kaynaklardan ve alandan toplanan özgün verilerden yararlanılarak hazırlanmıştır. Araştırmaya katılan kırsal kadınlara anket uygulanarak, öğrenim durumu, aile yapısı, gelir kaynaklarının neler olduğu, sosyal güvence durumları, aile içi kararlara katılımları gibi konular incelenmiştir. Araştırmada elde edilen sonuçlara göre, ankete katılan kadınların $\% 60.8$ 'i ilkokul mezunudur. Kadınlar, bitkisel üretimde çapalama ve ekim-dikim; hayvansal üretimde süt sağımı gibi üretimin her aşamasına katılmaktadır. Kadınlar en çok ailede giyim eşyalarının satın alınmasına (\%40.4) karar vermektedir. Eşlerin birlikte karar verdiği konuların başında ise sahip olunmak istenen çocuk sayısı (\%82.3) gelmektedir. Araştırmada elde edilen sonuçlarda aile içinde alınan ekonomik ve sosyal kararlarda etkili olan kişi genelde aile reisi olmaktadır. Araştırmada kırsal alanda yaşayan kadınların kooperatiflerden beklentilerini konumlandırmak üzere yapılan çok boyutlu ölçekleme (ÇBÖ) analizinden yararlanılmıştı. Araştırmada kırsal kesimdeki kadınların kooperatif ortaklığındaki önceliklerinin tarımsal girdi temini ve ürünlerini pazarlayabilmek olduğu belirlenmiștir.

Anahtar Kelimeler: Kırsal Kalkınma, Kırsal Kadın, İşgücü, Kooperatif

\begin{abstract}
Although the roles and functions of women are very important in rural places, they work as unpaid family workers in many areas. On the one hand, women carry out the daily chores; on the other hand, they contribute to the family budget by doing profitable works such as handcrafts and agricultural production. However, they do not contribute effectively to decisions made in the family or about production. The research includes 255 women living in 55 villages in Tekirdağ. The research has been prepared with data obtained from various written sources and from authentic data collected from the area. Through the questionnaire method done to rural women within the scope of the research, subjects such as rural family structure and education level of women, income sources, and contribution to decisions on agricultural production were examined. According to the results of the study, $60.8 \%$ of women who took part in the questionnaire are primary school graduates. Women contribute to every level of production by ploughing and planting in plant production; and milking animals in animal production. Women mostly decide on the purchase $(40.4 \%)$ of clothes in the family. The subject that couples decide together $(82.3 \%)$ is primarily on how many children they would have. According to the results of the study, the patriarch of the family is generally the effective on making on financial and social decisions. The research employs multi-dimensional scaling (MDS) analysis in order to position women's expectations from cooperatives. The study has determined that women's priorities in cooperative partnership are input supply and marketing their products.
\end{abstract}

Keywords: Rural Development, Rural Women, Work Power, Cooperative

\footnotetext{
1*Sorumlu Yazar/Corresponding Author: Emine Yılmaz, Tekirdağ Namık Kemal Üniversitesi Ziraat Fakültesi Tarım Ekonomisi Bölümü, Tekirdağ. E-mail: emineyilmaz@nku.edu.tr, (D) OrcID: 0000-0002-3434-8932

${ }^{1}$ Gülen Özdemir, Tekirdağ Namık Kemal Üniversitesi Ziraat Fakültesi Tarım Ekonomisi Bölümü, Tekirdağ. E-mail: gozdemir@nku.edu.tr@D OrcID: 0000-0003$3107-972 X$

'Yasemin Oraman, Tekirdağ Namık Kemal Üniversitesi Ziraat Fakültesi Tarım Ekonomisi Bölümü, Tekirdağ. E-mail: yoraman@nku.edu.tr iD OrcID: 0000-00016776-7861

${ }^{1}$ Gökhan Unakıtan, Tekirdağ Namık Kemal Üniversitesi Ziraat Fakültesi Tarım Ekonomisi Bölümü, Tekirdağ. E-mail: unakitan@nku.edu.tr D OrcID: 0000-00029824-5975

'Sema Konyalı, Tekirdağ Namık Kemal Üniversitesi Ziraat Fakültesi Tarım Ekonomisi Bölümü, Tekirdağ. E-mail: skonyali@nku.edu.tr D OrcID: 0000-00026049-495X

Atıf/Citation: Yılmaz, E., Özdemir, G., Oraman, Y., Unakıtan, G., Konyalı, S. Tarımsal üretimde kadınların karar alma süreçlerine katılımı ve kooperatiflerden beklentileri, Tekirdă̆ Ziraat Fakültesi Dergisi, 16(1), 71-81.
}

CBu çalışma Tekirdağ Namık Kemal Üniversitesi tarafından Creative Commons Lisansı (https://creativecommons.org/licenses/by-nc/4.0/) kapsamında yayınlanmıştır. Tekirdağ 2019 


\section{Extended Summary}

In the agriculture sector, female labor is not seen as an income-generating activity because women who work are unregistered, lack insurance, and constitute unpaid family workers involved in production, and they also are not reflected in the statistics. The fact that women are seen as an aid to cheap labor or family economy, and that most of their activities are considered as part of their natural life - not in the real sense of domestic work - cause a low perception of the work. The population of Turkey reached 80.810 .525 by the end of 2017 , and $92.5 \%$ of population lives in urban areas, while $7.5 \%$ lives in rural ones. Some $50.2 \%$ of total population is male, and $49.8 \%$ is female; also, $50.6 \%$ of total rural population is male, and $49.4 \%$ is female. There are no major differences between male and female population in urban and rural areas. The most important role assumed by women in rural areas is agricultural production. Women go through the struggles of production, but, unfortunately, they cannot make use of its benefits. The majority of women employed in agricultural labor in rural areas receives marginal jobs and work as unpaid family workers. Women contribute to the right and healthy nutrition of the family, which is the smallest unit of the social structure. Nutrition plays an important role in the education of children by transferring to new generations various patterns of behavior, as well as information and culture. As long as women carry out the tasks they assume, they contribute significantly to the developments in the socio-economic and cultural structure of society. Although the roles and functions of women are very important in rural places, they work as unpaid family workers in many areas. On the one hand, women carry out the daily chores; on the other hand, they contribute to the family budget by doing profitable works such as handcrafts and agricultural production. However, they do not contribute effectively to decisions taken in the family or about production. Although women largely take part in agricultural production in Turkey, their roles should be improved in marketing and entrepreneurship. Women cannot put forth their entrepreneurship skills in rural areas. Thus, their active participation in entrepreneurship and marketing processes will play a significant role for them to assume more active roles in both economic and social processes in rural areas.

The present research concerns 255 women living in 55 villages in Tekirdağ. It has been prepared with data obtained from various written sources and from authentic data collected from the area. Through the questionnaire method applied to rural women within the scope of the research, subject matters, such as rural family structure and education level of women, income sources, and contribution to decisions on agricultural production, were examined. According to the results of the study, some $60.8 \%$ of women who took part in the questionnaire are primary school graduates. Women contribute to every level of production by ploughing and planting in plant production, and by milking animals in animal production. Women decide mostly on the purchase $(40.4 \%)$ of clothes in the family. The subject on which the couples decide together $(82.3 \%)$ is primarily on how many children they would have. According to the results of the study, the husband and/or father of the family is actually in effect in making financial and social decisions. Our research employs multi-dimensional scaling (MDS) analysis in order to position women's expectations from cooperatives. The study has determined that women's priorities in cooperative partnership are input supply and the marketing of their products.

In order to increase the tendency to create various forms of communion in rural areas, trainings should be organized and the existing unions and organizations should be further developed. Cooperatives represent an important tool for women in rural areas. Therefore, women should be partners in cooperatives. Increasing the impact of women's existence and decision-making processes in cooperatives should be important in meeting the cultural, social and economic needs of women, as well as in meeting the needs for the production of goods and services within the scope of economic activities and their marketing. In this way, important steps would be made in reducing the poverty, increasing instead the income distribution of women living in rural and being involved in agricultural activities by providing them with different forms of cooperation and organization.

Women entrepreneurship in rural areas, the inadequacy of women's access to property, material resources and education, and low income levels limit the rate of traditional labor force participation. Women's cooperatives can be an important role model for women's labor force participation. 
Türkiye'de kırsal ve kentsel alanlarda kadınların işgücüne katılımlarında büyük farklılıklar vardır. Kırsalda çalışan kadınların oranı erkeklerin oranından daha fazladır. Kadın, şehirlerde ekonomik özgürlüğünü kazanabilmek için daha iyi şartlarda çalışırken, kırsal kesimde daha ağır şartlarda çalışmak durumundadır. Kırsalda kadının çalıştığı işler genellikle tarımsal faaliyetlere yöneliktir. Kadınlar ülkemizde kırsal kesim ekonomisini ayakta tutan temel bir güçtür. Tarımsal faaliyetlere de büyük ölçüde bedenen katılan kırsal kadınlar aile içinde de evinin kadını ve anne olarak büyük sorumluluklar taşımaktadırlar.

Kırsal alanda, kadının üretimdeki emek yoğunluğu çok yüksektir. Kırsalda kadınlar ve genç kızlar ücretsiz aile işçisi konumunda olup aynı zamanda ağır bir iş yüküne de sahiptirler (Fazlığlu 2002).

Kadın, toplumsal yapının en küçük birimi olan ailenin, doğru ve sağlıklı beslenmesine katkıda bulunur. Diğer taraftan çocuklarına davranış biçimlerini, bilgilerini ve kültürünü aktararak çocukların eğitiminde de önemli bir role sahiptir. Kadınlar üstlenmiş olduğu görevleri yaptıkları sürece, toplumun hem sosyo-ekonomik, hem de kültürel yapısındaki gelişmelere önemli katkı sağlamış olurlar.

Bu araştırma ile Tekirdağ İli’nde kırsal kesimdeki kadınların işgücüne ve üretime katılım düzeyleri, tarımsal üretim ile ilgili kararlara katılımları, kooperatif ortaklığındaki öncelikleri değerlendirilmeye çalışılmış ve öneriler ortaya konulmuştur.

\section{Materyal ve Yöntem}

$\mathrm{Bu}$ çalışmanın ana materyalini Tekirdağ ili merkezine bağlı 55 köydeki 255 kadından anketlerle sağlanan veriler oluşturmaktadır. Çalışmanın anket aşamasında uygulanacak anketlerin eksikliğini gidermek amacıyla pilot anketler hazırlanmıştır. Hazırlanan bu anketler tesadüfi olarak seçilen ailelere uygulanmıştır. Pilot anketlerden elde edilen sonuçlardan hareketle anket formları tekrar gözden geçirilmiş, düzenlemeler yapılmış ve esas anketler hazırlanarak anket çalışmasına başlanmıştır. Araştırmada konu ile ilgili daha önce yapılmış çeşitli araştırmalardan yararlanılmıştır. Çalışmanın örnek hacmi aşağıdaki formül yardımıyla hesaplanmıştır (Malhotra, 1999).

$$
n=\frac{N \cdot p(1-p)}{(N-1) \sigma_{p x}^{2}+p(1-p)}
$$

Formülde N: populasyon, n: örnek hacmi, p:populasyonun özelliği (kırsal kesimde kadınların oranı), (1-p): kırsal kesimde erkeklerin oranı, oranların standart sapması, $\mathrm{d}$ : örnekleme hata payı, $\mathrm{Z}_{\alpha / 2}$ güven aralığ1

Tekirdağ merkez ile bağl1 55 köyde 4601 hane halkı bulunmaktadır. Yukarıdaki örnekleme formülüne göre \%95 güven aralığı ve 0,05 hata payı dikkate alındığında örnek hacmi 255 olarak hesaplanmıştır. Her bir hanede bir kadın bulunduğu varsayımından hareketle en yüksek örnek hacmine ulaşabilmek üzere p ve (1-p) 0,50 kabul edilmiştir. Örnek hacmi Tekirdağ merkez ile bağlı köyler arasında oransal olarak dağıtılmıştır. Çalışma kapsamında 55 adet köyün tamamı ziyaret edilerek, örnek hacmini oluşturan 255 haneden birer kadın ile yüz yüze görüşülmüştür.

Anket sonuçlarının değerlendirilmesinde kırsal alanda yaşayan kadınların kooperatiflerden beklentilerini konumlandırmak üzere yapılan çok boyutlu ölçekleme (ÇBÖ) analizinden yararlanılmıştır.

\section{Kadınların Demografik Yapısı}

\section{Araştırma Bulguları}

İklim ve arazi koşullarındaki olumsuzluklar, köyde yaşamayı zorlaştırmaktadır. Tüm aile bireylerinin yaşadığı bu zorluğu kadınlar çok daha fazla yaşamaktadır. Çünkü kadın, günlük hem ev işleri ve hem de ev dışındaki işlerde yoğun bir şekilde emek harcamakta, erkeğin çalışmak için köy dışına çıkması nedeni ile de ailenin yükünü tek başına üstlenmektedir. Böylece kadın, ailenin gıda güvenliğinde ve kırsal kalkınmada da önemli bir rol oynamaktadır (Demir, 2002).

Kadınların yaşları diğer nitelikleri arasındaki ilişkileri ortaya çıkarması bakımından önem taşımaktadır. Yaş, Türk toplumunda bireylerin kabul görmesinde, toplumda belli bir yer edinmesinde, ayrıca kendilerini ve çevrelerini belirli bir biçim ve düzeyde etkilemelerinde önemlidir (Yıldırak ve ark., 2003). Bu sebeple araştırma kapsamındaki kırsal kadınların yaş durumları Çizelge 1' de verilmiştir. 
Çizelge 1. Ankete Katılan Kadınların Yaş Durumu

Table 1. Age Status of Women Participated in the Survey

\begin{tabular}{ccc}
\hline Yaş & Sayı & Oran (\%) \\
\hline $\mathbf{1 5 - 2 4}$ & 21 & 8.2 \\
\hline $\mathbf{2 5 - 3 4}$ & 49 & 19.2 \\
\hline $\mathbf{3 5 - 4 4}$ & 86 & 33.7 \\
\hline $\mathbf{4 5 - 5 4}$ & 66 & 25.9 \\
\hline $\mathbf{5 5 - 6 4}$ & 22 & 8.6 \\
\hline $\mathbf{6 5 - +}$ & 11 & 4.2 \\
\hline Toplam & 255 & 100 \\
\hline
\end{tabular}

Çizelge 1'de kadınların yaş gruplarına göre dağılımı verilmiştir. Çizelgeden görüldüğü gibi kadınların yaklaşık \%33.7'sinin 35-44 yaş grubunda olduğu, bunu sırasıyla \%25.9 ile 45-54 ve yine \%19.2 ile 25-34 yaş grubunun izlediği görülmektedir.

Kalkınmanın odak noktasının insan olarak dikkate aldığımızda, dünyadaki bütün ülkeler eğitimi önemli bir yatırım aracı olarak kabul etmektedirler. Durum böyleyken, ülkemizde kırsal kesimdeki kadınlar, eğitim açısından olumsuz koşullarda bulunmaktadır (Karataş,1997; Özgen ve Ufuk, 2011).Tekirdağ köylerinde yaşayan anket katılımcısı kadınların eğitim düzeyleri Çizelge 2‘de verilmiştir.

\section{Çizelge 2. Ankete Katılan Kadınların Eğitim Durumu}

Table 2. Education Status of the Surveyed Women

\begin{tabular}{ccc} 
& Sayı & Oran (\%) \\
\hline İlkokul & 155 & 60.8 \\
\hline Ortaokul & 51 & 20.0 \\
\hline Lise & 37 & 14.5 \\
\hline Üniversite & 12 & 4.7 \\
\hline Toplam & 255 & 100 \\
\hline
\end{tabular}

Ankete katılan kadınların eğitim durumları incelendiğinde, \%60.8'sinin ilkokul mezunu olduğu görülmektedir. Ortaokul mezunları \%20, lise mezunlarının oranı \%14.5, üniversite mezunu olanların oranı ise \%4.7'dir.

Schultz'a göre; kadını eğitmek, verimlilik artışı sağlar ve buna bağlı olarak da kişisel ücret getirilerini arttırır, doğurganlığı ve çocuk ölümlerini azaltır. Kadının sosyal çevresinin dışa açılmasını sağlar, çocukların iyi bir eğitim ve sağlık olanaklarına erişmesiyle kuşaklar arası farklılıkları giderir, geliri düşük ve yüksek olanlar arasında firsat eşitliği sağlar. Bir kadını eğitmek, bir aileyi ve bir toplumu eğitmekle eşdeğerdir (Bubolz, 2001). Kadın eğitiminin, toplumun gelişmesine olumlu katkı sağladığının bilinmesine rağmen, özellikle gelişmekte olan ülkelerde, kadınların eğitimine daha fazla önem verilmesi gerektiği dikkate alınmamaktadır (Yumuşak, 2004). Çalışmada görüldüğü üzere kırsaldaki kadınları eğitim düzeyi büyük bir çoğunlukla ilkokul ve ortaokul düzeyinde olup, eğitim seviyesinin yükseltilmesi açısından daha çok yol alınması gerektiği ortaya çıkmaktadır.

\section{Kadınların İşgücüne Katılım Durumu}

Dünyada olduğu gibi Türkiye'de de tarım ve hayvancıllk sonucunda elde edilen ürünler, gıda güvenliğinin önemli bir parçasıdır ve bu faaliyetler çoğunlukla kadınlar tarafından yerine getirilir. Türk toplumunda kırsaldaki kadınlar büyük ölçüde üretime katılmakta ve ekonomik kalkınmaya katkı sağlamaktadır. Araştırmanın yapıldığı Tekirdağ'ın köylerinde de kadınların tarım ve hayvancılık faaliyetlerine katılımları oldukça yüksek düzeydedir.

Sosyo-ekonomik faktörler sebebiyle son yıllarda genç neslin göç ederek tarımsal faaliyetlerden uzaklaşması farklı iş sektörlerinde çalışmaya başlaması, kadınların ev içi ve dışında yeni görev ve sorumluluklar yüklenmesine neden olmuştur. Kadınlar ev içindeki görev ve sorumluluklarının dışında hayvansal ve bitkisel üretimde de emek yoğun faaliyetlere katılmak durumunda kalmışlardır. Ülkemizde yapılan araştırmalara bakıldığında kadınların işgücüne katılımı başlıca üretim faaliyeti ve işletmenin mekanizasyon düzeyi gibi pek çok etken tarafından belirlenmektedir. Örneğin kadınlar hasat sonrası faaliyetlere veya hayvansal üretim faaliyetine, erkeklerden çok daha fazla katılmaktadır. Aile düşük mekanizasyon düzeyine sahip olunduğunda da kadınlar tarımsal faaliyetlerde daha fazla yer almaktadır (Özçatalbaş, 2001). 
Ankete katılan kadınların tarımsal faaliyetlerde yaptıkları işler, hayvansal üretim ve bitkisel üretim şeklinde iki gruba bölünerek Çizelge 3'te verilmiştir.

Çizelge 3 incelendiğinde, kadınların bitkisel üretim faaliyet alanında en çok (\%78.4) çapalama, ekim (\%64.3), dikim (\%60.8) işlerinde çalıştıkları görülmektedir. Sulamada çalışan kadınların oranı \% 54.0, toprağı ekime hazırlamada çalışanların oranı \%39.6, hasatta çalışanların oranı \%37.6, gübrelemede çalışanların oranı \%33.7, ilaçlamada çalışanların oranı \%21.6 olarak belirlenmiştir. Hayvansal üretimle ilgili faaliyetlere bakıldığında, kadınların \% 76,5'inin süt sağımı, \%61,2'sinin ahır-ağıl temizliği, \%62,0'sinin hayvan besleme, \%58,0'inin hayvan sulama, \%38,0’inin hayvan otlatma işlerini yaptığı görülmektedir. Elde edilen bu bilgilere göre kırsalda kadınların tarımsal üretimin her aşamasında yer aldıklarını söylemek mümkündür.

\section{Çizelge 3. Tarımsal Faaliyetlerde Kadınların Yaptıkları İşler}

Table 3. Women's Works in Agriculture

\begin{tabular}{|c|c|c|c|}
\hline Tarımsal faaliyet & Yapılan işler & Kadın sayısı & Oran $(\%)$ \\
\hline \multirow{13}{*}{ Bitkisel Üretim } & Ekim & 164 & 64.3 \\
\hline & Dikim & 155 & 60.8 \\
\hline & Sulama & 140 & 54.0 \\
\hline & Toprağı Ekime Hazırlama & 101 & 39.6 \\
\hline & Gübreleme & 86 & 33.7 \\
\hline & Çapa Yapma & 200 & 78.4 \\
\hline & Budama & 61 & 23.9 \\
\hline & Hasat & 96 & 37.6 \\
\hline & Taşıma & 81 & 31.8 \\
\hline & Ürün Pazarlama & 49 & 19.2 \\
\hline & İlaçlama & 55 & 21.6 \\
\hline & Aş1 Yapma & 21 & 8.2 \\
\hline & Tohum Ekme & 122 & 47.8 \\
\hline \multirow{6}{*}{ Hayvansal Üretim } & Ahır-Ağıl Temizliği & 156 & 61.2 \\
\hline & Yem Hazırlama & 151 & 59.2 \\
\hline & Süt Sağımı & 195 & 76.5 \\
\hline & Hayvan Beslemesi & 158 & 62.0 \\
\hline & Hayvan Otlatma & 97 & 38.0 \\
\hline & Sulama & 148 & 58.0 \\
\hline
\end{tabular}

Not: Sorulara birden fazla cevap vermiştir.

Araştırma alanındaki hayvancılık faaliyetleri çoğunlukla kadınlar tarafından yerine getirilmektedir. Bakılabilecek hayvan çeşidi ve sayısının belirlenmesi, satılacak hayvanların hangileri olduğunun kararının verilmesi genellikle kadınlara aittir. Hayvanların sağılması, bakımı, sütün işlenerek ikincil ürünlere dönüştürülmesi çoğunlukla kadınların sorumluluğundadır.

\section{Kadınların Aile İçi Kararlara Katılımı}

Türkiye'de genellikle kırsal ya da kentsel alanda aile biçimlerine göre farklılık olsa da karar aşamasında erkekler daha etkin rol almaktadır. Günümüzde hızla değişen dünya koşulları içerisinde kentleşme, ulaşım, sağlık, eğitim, göç ve teknolojideki gelişmelere koşut olarak, kadınların aile içi ve dışı ilişkilerinde, üretim süreçlerindeki rollerinde, kararlara katılımlarında olumlu yönde bir gelişme olmamaktadır. Kırsal kadının topluluk düzeyinde etkili olamaması temel olarak geleneksel cinsiyete dayalı tabakalaşma ve eğitim düzeyinin düşüklüğünden kaynaklanmaktadır. Karar vermede söz sahibi olamama her kesimdeki kadınlar tarafından hissedilen, ama kırsal alan kadınlarında daha belirgin olan bir gerçektir (Fazlığlu 2001).

Kırsalda aile içerisinde erkek, kadın ve çocuklar farklı konumlarda bulunurlar. Genellikle aile içerisinde bütün dikkatler ilk önce baba, sonra erkek çocuklar üzerinde toplanmakta ve kadın ise ikinci planda yer almaktadır. Karar alma işlemi zihinsel bir faaliyet sonucunda ortaya çıkmakta ve bu işlem bir süreci gerektirmektedir. Bu yönüyle kırsalda yaşayan kadınların tarımsal üretim faaliyetinin karar sürecine katılmaları ekonomik anlamda bir iştir. Bu nedenle tarımsal işletmede alınan kararlara katılım, üretim faaliyetine katılım kadar incelemeye değerdir. (Merter, 
1990).

Kadınlarla erkeklerin aynı oranda karar verme sürecine katılması, ülkemizde önemli engellerle karşılaşmıştır. Bu engellerin bir bölümü toplumsal bir bölümü ise kültüreldir. Aile sisteminde karar verme bir uzlaşma biçimidir. Kırsal alandaki kadının karar verme sürecine katılımı ailedeki ataerkil yapının boyutları ve kadının statüsü ile yakından ilişkilidir (Bayoğlu, 2010).

Anket yapılan kadınların \%52.1'i arazi satın alınıp satılmasına ailede erkeklerin karar verdiklerini belirtmişlerdir. Kadınlar en çok ailede giyim eşyalarının satın alınmasına (\%40.3), ikinci sırada da hangi siyasi partiye oy verileceğine (\%36.0) karar vermektedirler. Eşlerin birlikte karar verdiği konuların başında ise sahip olunmak istenen çocuk sayısı (\%82.3) gelmektedir. Araştırmada elde edilen sonuçlarda aile içinde alınan ekonomik ve sosyal kararlarda etkili olan kişi genelde aile reisi olmaktadır.

Çizelge 4. Kırsal ailede kadının kararlara katılımı

Table 4. Women's participation in decisions in rural family

\begin{tabular}{|c|c|c|c|c|c|c|c|c|c|c|}
\hline \multirow{2}{*}{ Kararlar } & \multicolumn{2}{|c|}{ Kadın } & \multicolumn{2}{|c|}{ Erkek } & \multicolumn{2}{|c|}{ Eşler Birlikte } & \multicolumn{2}{|c|}{$\begin{array}{l}\text { Aile Üyeleri } \\
\text { Birlikte }\end{array}$} & \multicolumn{2}{|c|}{ Toplam } \\
\hline & Say1 & $\begin{array}{c}\text { Oran } \\
(\%)\end{array}$ & Say1 & $\begin{array}{c}\text { Oran } \\
(\%)\end{array}$ & Say1 & $\begin{array}{c}\text { Oran } \\
(\%)\end{array}$ & Say1 & $\begin{array}{l}\text { Oran } \\
(\%)\end{array}$ & Say1 & $\begin{array}{c}\text { Oran } \\
(\%)\end{array}$ \\
\hline Araç Gereç Satın alımı & 16 & 6.27 & 113 & 44.31 & 99 & 38.82 & 27 & 10.58 & 255 & 100 \\
\hline $\begin{array}{l}\text { Yeni teknolojik araç gereçlerin } \\
\text { kullanılmasına }\end{array}$ & 13 & 5.09 & 116 & 45.49 & 92 & 36.07 & 34 & 13.33 & 255 & 100 \\
\hline Arazi satın alınıp satılmasına & 4 & 1.56 & 133 & 52.15 & 81 & 31.76 & 37 & 14.50 & 255 & 100 \\
\hline $\begin{array}{l}\text { Yeni bir tarımsal ürün çeşidinin } \\
\text { üretimine }\end{array}$ & 29 & 11.37 & 126 & 49.41 & 68 & & 32 & 12.54 & 255 & 100 \\
\hline Ürünlerin ne zaman satılacağına & 33 & 12.94 & 123 & 48.23 & 68 & 31.76 & 31 & 12.15 & 255 & 100 \\
\hline Aile gelirinin harcanmasına & 19 & 7.45 & 48 & 18.82 & 150 & 58.82 & 38 & 14.90 & 255 & 100 \\
\hline Ev eşyalarının satın alınmasına & 55 & 21.56 & 24 & 9.41 & 142 & 55.68 & 34 & 13.33 & 255 & 100 \\
\hline $\begin{array}{l}\text { Giyim eşyalarının satın } \\
\text { alınmasına }\end{array}$ & 103 & 40.39 & 6 & 2.35 & 116 & 45.49 & 29 & 11.37 & 255 & 100 \\
\hline Çocukların öğrenim süresine & 15 & 5.88 & 28 & 10.98 & 133 & 52.15 & 53 & 20.78 & 255 & 100 \\
\hline $\begin{array}{l}\text { Kadının tarım dışı bir işte } \\
\text { çalışmasına }\end{array}$ & 55 & 21.56 & 48 & 18.32 & 130 & 50.98 & 34 & 13.33 & 255 & 100 \\
\hline $\begin{array}{l}\text { Seçimlerde hangi siyasi partiye } \\
\text { oy verileceğine }\end{array}$ & 92 & 36.07 & 36 & 14.11 & 191 & 74.90 & 27 & 10.58 & 255 & 100 \\
\hline $\begin{array}{l}\text { Sahip olunmak istenen çocuk } \\
\text { sayısına }\end{array}$ & 13 & 5.09 & 18 & 7.05 & 210 & 82.35 & 11 & 4.31 & 255 & 100 \\
\hline
\end{tabular}

Kırsal alanda yapılan birçok araştırmada kadınların, tarımsal üretim faaliyetlerine katılmalarına rağmen, tarımsal üretimle ilgili alınan kararlarda karar verici olarak değil de kararın oluşmasında katkıda bulunan olduğu görülmüştür. Kadınlar aile içinde alınan birçok kararda da etkili olamamaktadır. Konya ilinde yapılan bir araştırmada erkeklerin tarım dışı işlerde çalışması kadın işgücü kullanımını arttırdığı, fakat kadınların işletme ile ilgili kararlarda pek fazla etkili olamadıkları belirlenmiştir (Mülayim, 1999). Amerika Birleşik Devletlerinde kırsal alanda yaşayan kadınların tarımsal faaliyetlere ve kararlara katılımının araştırıldığı bir çalışmada, işletmede uygulamaya yönelik kararları genellikle eşin ya da aile büyüğü olan başka bir erkeğin verdiği, kadınların \%2-4 oranıyla son derece düşük bir katılıma sahip olduğu belirlenmiştir (Rosenfeld, 1986).

Antalya ilinde sera sebzeciliğinde çalışan üretici kadınlarla yapılan bir araştırmada, kadınların serada sebze üretiminde işgücü olarak çok büyük katkıları olmasına rağmen işletmede pazarlama ve üretim ile ilgili konularda alınan kararlarda etkili olarak rol almadığı belirlenmiştir (Özkan 2000). Kentucky’de yapılan bir çalışmada ise kırsal alanda işleri yapan kadınlar olmalarına rağmen, işletme ile ilgili kararlara katılımlarının düşük olduğu görülmüştür (Bokemier ve Garkouich,1987). Elde edilen bu veriler bize, kadınların tarımsal üretim ile ilgili birçok faaliyete katılmasına rağmen, karar alma mekanizmasında yeterince etkili olamadıklarını göstermektedir.

Trabzon ilinin orman köylerinde kırsal kadınlarla yapılan bir çalışmada, kadınların \%71,0’i aile ile ilgili önemli kararlar alınırken eşlerinin kendilerine danıştığını belirtmişlerdir (Alkan ve Toksoy, 2009). Konya ilinin Yaylacık Köyünde yapılan bir araştırmada kadınlara aile gelirinin harcanmasında kararı kimler verir diye sorulduğunda kadınların, \%40,0’1 kocasının karar verdiğini, \%36,4’ü kocası ile birlikte karar verdiklerini, \%21,8’i tüm aile 
bireyleri ile birlikte karar verdiklerini, \%1,8’i yalnızca kendisinin karar verdiğini belirtmiştir (Oğuz ve Kan, 2010).

Kırsal alanda yaşayan kadınların, tarımsal üretim faaliyetlerinin her aşamasına katıldıkları ancak alınacak kararlarda çoğu zaman etkili olamadıkları Kulak (2011), Oğuz ve Kan (2010), Özer ve Taluğ (2008), Kutlar (2002), Özçatalbaş (2001), Özkan (2000), Mülayim (1999) ve Hablemitoğlu (1996) tarafindan da tespit edilmiştir. Yapılan bir çalışmada da kırsal alanda yaşayan kadınların \%24,3'ünün elde ettikleri kazançlarının kullanımına ilişkin karar sürecinde de hiçbir söz hakkı olmadığı görülmüştür (Kulak, 2011). Kırsal alanda kadın gelir getirici bir işte çalışsa bile elde ettiği geliri eşine vermekte ya da ailenin ihtiyaçları için harcamaktadır. Bu sonuçlardan da anlaşıldığ 1 üzere verilen örnekler araştırma bulgularını destekler niteliktedir.

Kadınların Kooperatife, Birliğe, Derneğe Ortak veya Üye Olma Durumları ve Kooperatiflerden Beklentileri

Fertlerin tek başlarına yapamayacakları veya birlikte yapmalarında fayda bulunan işleri en iyi bir biçimde ve maliyet fiyatına yapmak üzere dayanışma suretiyle ekonomik güçlerini bir araya getirmelerine kooperatif denilmektedir (Mülayim, 1992). Ülkemizde sayısal olarak 4-5 milyon ortağ bulunan tarımsal kooperatifler çeşitli alanlarda faaliyet göstermesine rağmen, batı ülkelerinde olduğu gibi etkili değildir (Yılmaz ve Gül, 2010). Araştırma kapsamındaki kadınlara tarımsal kalkınma kooperatifi, tarım kredi kooperatifi, pancar kooperatifi, ziraat odası, üretici birliği, önder çiftçi deneği gibi kooperatif ve diğer kuruluşlara ortak olup olmadığı sorulmuş, \%79.3'ü üye veya ortak olmadıklarını ifade etmişlerdir.

Üye veya ortak olduğunu belirten kadınlara (53 kadına) "hangisine üyesiniz?" diye sorulduğunda, kadınların $\%$ 32,0'1 ziraat odasına, \%19,0'ı üretici birliğine, \% 13.22'si tarım kredi kooperatifi- tarım kalkınma kooperatifi, $\% 11.3$ 'ü önder çiftçi- pancar kooperatifine üye- ortak olduğunu belirtmiş̧tir.

Özdemir ve ark. (2017) Trakya Bölgesinde yapmış oldukları araştırmada da kadınların \%30.2'si Trakya birliğe, \% 21'i Ziraat odasına, \%16.8'i tarım kredi kooperatifine, \%15.9'u pancar kooperatifine üye- ortak olduğu görülmektedir. Bölgede yapılan araştırmalar da hemen hemen aynı sonucu desteklemektedir.

Kooperatifler, ekonomik açıdan darda ve zorda olan kadınların ekonomik gelişmeleri için oldukça önemli araçlardır. Kooperatiflerin kurulmasında dikkat edilmesi gereken nokta, tabandan gelen gönüllü bir hareketle kurulmalarıdır. Kadınlar gerçekten ihtiyaç duyarak bu harekete başlamalıdır. Türkiye'de tarımda yer alan bazı kooperatif örneklerine bakılacak olursa, yıllarca devlet güdümlü ve ortakların sahiplenmediği kooperatifler olarak varlıklarını sürdürdükleri görülmektedir. Bunlar olumsuz birer örnek olarak karşımıza çıkmaktadır. Ancak bunların yanında bağımsız, tıpkı kadın kooperatiflerinde olduğu gibi tabandan gelen örgütlenme ile kurulmuş kooperatifler de ekonomik olarak güçsüz ve dağınık bir yapıda gelişmelerini sürdürmektedirler. Bu nedenlerden dolayı kadın kooperatiflerinin aynı duruma düşmemeleri için, kooperatifleşmeyi bilinçli bir şekilde örgütlemek ve yönetmek gerekmektedir (Özdemir, 2013).

Araştırmaya katılan kadınlara destek verildiğinde kendi aralarında kooperatif kurmayı düşünür müsünüz? diye sorulduğunda kadınların \%60.7'si evet, \% 39.2'si hayır cevabını vermiştir.

Doğanay (1993)'ın da bildirdiği gibi kooperatif politikasının amacı, tarımsal üretimin ulusal kalkınmaya olan dolaylı ve dolaysız katkılarını en yüksek düzeye ulaştırma ve bu gereklere uygun nicelik ve niteliklerde tarımsal ürün türlerinin üretilmesini gerçekleştirmektir. Bunun anlamı ise tarım kesiminin planlanmasında kooperatifçiliğin etkin bir araç olarak kullanılabileceğidir. Kooperatifçilik uygulamaları, tarımsal üretimi planlamanın etkin araçlarından birisi olarak kullanılabilirse, tarımsal gelir ve üretimdeki artı̧̧ hızları hem istenilen büyüklüğe ulaştırılabilir hem de tarımsal üretimde yıldan yıla görülen değişiklikler ortadan kaldırılabilir. Türkiye'de tarım küçük üreticiler tarafından yapılmakta ve küçük üreticiler fiyatların oluşmasında tek başına yeterli olamamaktadırlar.

Çizelge 5. Kooperatif Kurulduğunda Kadınların Kooperatiften Beklentileri

Table 5. Women Expectations From Cooperative When Cooperative Founded

\begin{tabular}{lccccc} 
& $\begin{array}{c}\text { Hiç Önemli } \\
\text { değil }\end{array}$ & Önemli değil & $\begin{array}{c}\text { Fark } \\
\text { etmez }\end{array}$ & Önemli & Çok önemli \\
\hline Tecrübeleri paylaşmak & 2.0 & 1.6 & 5.1 & 41.9 & 43.8 \\
\hline Gelir elde etmek & 0.4 & 2.7 & 0.8 & 32.9 & 54.1 \\
\hline İhtiyaç sahiplerine yardımcı olmak & 0.4 & 2.4 & 4.3 & 34.1 & 54.1 \\
\hline Tarımsal girdi săglamak & 0.4 & 0.8 & 5.1 & 50.3 & 39.3 \\
\hline Ürünü pazarlamak & 0.4 & 0.4 & 5.5 & 27.7 & 61.9 \\
\hline
\end{tabular}

Kooperatif kurmayı düşünen kadınlara kooperatif kurulduğunda kooperatiften beklentileri sorulduğunda 
\%61.9'u ürününü pazarlamanın, \%54.2'si gelir elde etmek ve ihtiyaç sahiplerine yardımcı olmanın çok önemli olduğunu belirtmişlerdir.

Kırsal alanda yaşayan kadınların kooperatiflerden beklentilerini konumlandırmak üzere yapılan çok boyutlu ölçekleme (ÇBÖ) analizinden yararlanılmıştır.

Çok boyutlu ölçekleme analizi sonucunda iki boyutlu gösterim incelendiğinde Kruskal'ın (1978) geliştirdiği stres değerinin 0,00766 olduğu görülmektedir. Bu değer veri ve konfigürasyon uzaklıkları arasındaki uyumun tam olduğunu ifade etmektedir. Elde edilen matrise ait determinasyon katsayısı $\left(R^{2}\right) 0,99$ hesaplanmıştır. Çalışmada ele alınan verilerin geometrik gösterimi lineer form ile uyumlu sonuçlar vermektedir. Bu sonuç, gözlem uzaklıkları ve farklılıklar arasında lineer bir ilişki olduğu anlamına gelmektedir (Stres $=0,00766<0,025$ ). Şekil 3.1 'de verilen Shepard diyagramı gözlenen uzaklıklar ile konfigürasyon uzaklıklarının dağılımını göstermektedir.

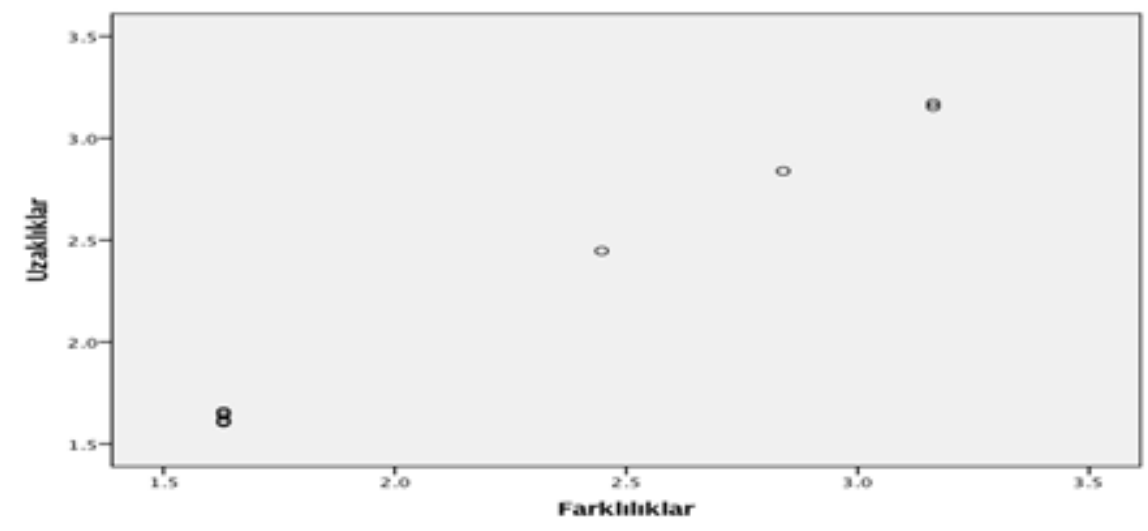

Şekil 1. Shepard Diyagramı

Figure 1. Shepard Diagram

Çok boyutlu ölçekleme analizinin iki boyutlu grafiği ekonomik ve sosyal faktörler olarak belirlenmiştir. Kadınların kooperatiflerden beklentilerinin dağılımı Şekil 3.2'de verilmiştir. Ekonomik boyut incelendiğinde tarımsal girdi tedariki ve ürünlerin pazarlanması pozitif yönde konumlandırılırken, gelir elde etme isteği negatif bölgede konumlanmıştır. Aslında uygun fiyatlarla girdi tedarik edilmesi ve ürünlerin pazarlanması doğrudan gelirin arttırılmasına yönelik beklentilerdir. Ancak deneklerin gelir elde etme isteğini doğrudan doğruya belirtemedikleri görülmektedir.

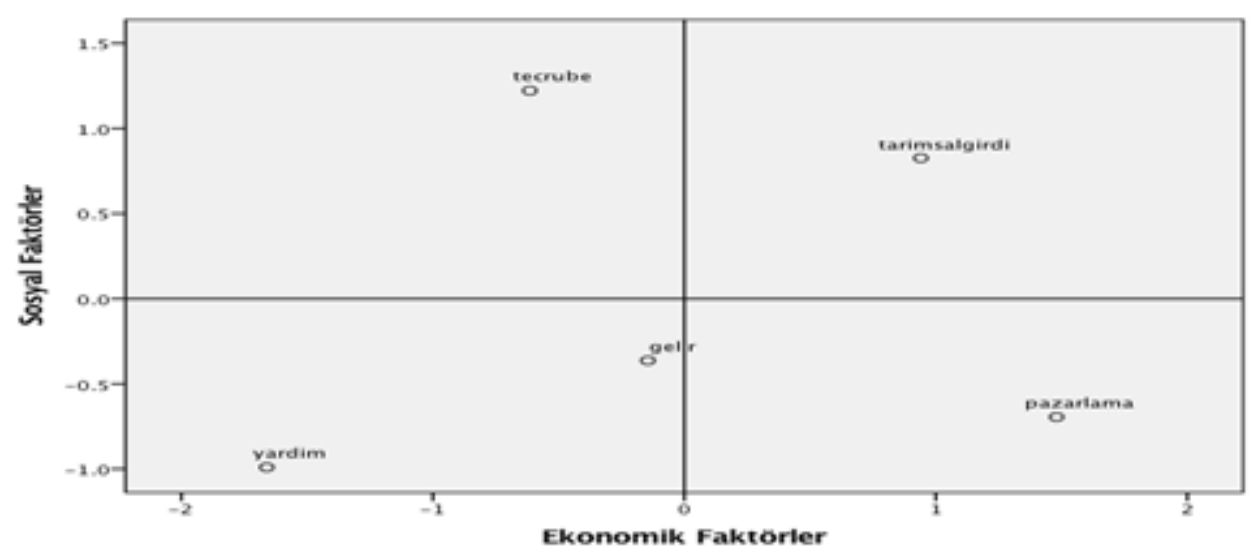

Şekil 2. Kooperatif kurulduğunda beklentiler

Figure 2. Expectations when the cooperative is established

Dağılımın sosyal boyutu incelendiğinde ise kadınların çeşitli konularda tecrübe edinme isteklerinin pozitif yönde konumlandığı görülürken ihtiyaç sahiplerine yardımcı olmak kriterinin negatif yönde konumlandığı görülmektedir. Buna göre kırsal kesimdeki kadınların kooperatif ortaklığındaki önceliklerinin tarımsal girdi temini 
ve ürünlerini pazarlayabilmek olduğu söylenebilmektedir.

\section{Sonuç}

Araştırma sonuçlarını değerlendirdiğimizde, kırsal kesimde yaşayan kadınların hem hayvansal hem de bitkisel üretimin her aşamasına katkıda bulundukları ve eğitim düzeylerinin oldukça düşük olduğunu görmekteyiz. Kırsalda kadınların ekonomik katkıları fazla olmasına rağmen bu katkı görünmez nitelikte olduğundan kadınlar hak ettikleri yerin gerisinde kalmaktadır.

Araştırmaya katılan kadınların \% 56,1'inin sosyal güvencesinin olduğu belirlenmiştir. Sosyal güvencesi olan kadınların eşinden dolayı BAĞ-KUR, SSK ve emekli sandığı ile sosyal güvenceye sahiptir. Ailelerin \%47,6'sının 50 dönümden az araziye sahip olduğu görülmektedir.

Kadınların bitkisel üretim faaliyet alanında en fazla ekim, dikim, çapalama işlerinde çalıştıkları anlaşılmaktadır. Hayvansal üretimle ilgili faaliyetlere katılımlarına bakıldığında, kadınların hayvan besleme, süt sağımı, sulama, ahır-ağıl temizliği gibi işleri yaptığı belirlenmiştir. Kırsalda kadınların tarımsal üretimin her aşamasında yer aldıkları görülmektedir.

Araştırma alanındaki hayvancılık faaliyetleri çoğunlukla kadınlar tarafından yerine getirilmektedir. Bakılabilecek hayvan sayısı ve çeşidinin belirlenmesi, satılacak hayvanların hangileri olduğunun kararının verilmesi genellikle kadınlara aittir. Hayvanların sağılması, bakımı, sütün işlenerek ikincil ürünlere dönüştürülmesi çoğunlukla kadınların sorumluluğundadır.

Araştırma kapsamındaki kadınlara tarım kredi kooperatifi, tarımsal kalkınma kooperatifi, pancar kooperatifi, ziraat odası, üretici birliği, önder çiftçi derneği gibi kooperatif ve diğer kuruluşlara üye veya ortak olup olmadığı sorulmuş, \%79.3'ü üye veya ortak olmadıklarını ifade etmişlerdir. Üye veya ortak olduğunu belirten kadınların \% 32.0’1 ziraat odasına üye- ortak olduğunu belirtmiştir.

Kooperatif kurmayı düşünen kadınlara kooperatif kurulduğunda kooperatiften beklentileri sorulduğunda ürününü pazarlamanın, gelir elde etmek ve ihtiyaç sahiplerine yardımcı olmanın çok önemli olduğunu belirtmişlerdir.

Çok boyutlu ölçekleme analizinin ekonomik boyutu incelendiğinde tarımsal girdi tedariki ve ürünlerin pazarlanması pozitif yönde konumlandırılırken, gelir elde etme isteği negatif bölgede konumlanmıştır. Aslında uygun fiyatlarla girdi tedarik edilmesi ve ürünlerin pazarlanması doğrudan gelirin arttırılmasına yönelik beklentilerdir. Ancak deneklerin gelir elde etme isteğini doğrudan doğruya belirtemedikleri görülmektedir. Bu sonuç özellikle kırsal alanda kadınların karara alma süreçlerine katılımı açısından önemli bir bulgudur. Kadınların hala gelir elde etmek konusunda geri planda kaldıkları ve bu konuda aktif hale gelebilmeleri için eğitilmeleri gerekmektedir. Daha önce Özdemir ve ark.(2015) yaptığı bir çalışmada kadınların çiftçiliği meslek olarak kabul etmemeleri de bu sonucu destekler niteliktedir.

Toplumun sosyal, ekonomik ve kültürel açılardan gelişmesi cinsiyet açısından kadın ve erkeklerin eşit imkanlara sahip olmasına bağlıdır. Toplumu oluşturan bireylerin bütün olanaklardan eşit oranda yararlanması toplumun dengeli kalkınmasında oldukça önemlidir. Toplumun bütün kesiminde, her konuda başarı sağlamanın en önemli koşulu eğitimdir. Kırsal kesimdeki erkeklerin ve kadınların eğitim düzeyleri verilecek eğitimlerle yükseltilmelidir. Böylece eşler arasında iş bölümü ve yardımlaşma da artırılabilir. Kadınların karar verme sürecine daha fazla katılmaları için gerekli girişimler planlanarak hayata geçirilmelidir. Kırsal kadınların bilgi ve becerilerini geliştirmek için çeşitli kurslar düzenlenmeli, aynı faaliyetlerde bulunan kadınların örgütlenmeleri sağlanmalı, sosyal güvenlik hizmetleri sunarak kadınların kendi ayakları üzerinde durmaları ve kendilerini ifade edebilmeleri için ortam oluşturulmalıdır.

Kırsal alanda örgütlenme eğilimini arttırmak için eğitimler yapılarak mevcut olan örgütler geliştirilmelidir. Kırsal alandaki kadınlar için kooperatifler önemli birer araç niteliğini taşımaktadır. Bu nedenle kadınların kooperatif ortağı olmaları sağlanmalıdır. Kooperatiflerde kadın varlığının ve karar verme süreçlerindeki etkisinin artırılması kadınların kültürel, sosyal ve ekonomik ihtiyaçlarının karşılanmasında ve ekonomik faaliyetler kapsamında yer alan mal ve hizmet üretimi ile bunların pazarlanmasına yönelik ihtiyaçların karşılanmasında önemli olacaktır. Bu şekilde kırsalda yaşayan ve tarımsal faaliyet içinde bulunan kadınların kooperatifleşme, örgütlenme ile daha fazla gelir elde etmelerine katkıda bulunarak, yoksulluğun azaltılması ve gelir dağılımının iyileştirmesinde önemli bir adım olacaktır.

Tarımsal üretimin bütün aşamalarında yer alan kırsal kadınların ihtiyaç duydukları tüm konulardaki bilgilerin yerinde sağlanması ve kendilerine hak ettikleri değerin verilmesi gerekmektedir. Kadınlara yönelik gerçekleştirilen bütün projeler ve faaliyetler, yetiştirmiş oldukları çocuklara ve böylece de nesilden nesille aktarılmış olacaktır. Bu 
konuda yapılan çalışmalar ne kadar verimli olursa, yeni yetişen nesillerin de o kadar bilinçli olarak yetişeceğini söyleyebiliriz.

\section{Teşekkür}

Bu çalışma NKUBAP.00.24.AR.10.07 nolu "Kırsal Kalkınmada Kadının Yeri” isimli Projeden üretilmiştir. NKUBAP 'a teşekkürü borç biliriz. 


\section{Kaynakça/References}

Bayoğlu, A.S. (2010). "Kırsal Alanda Kadının Ekonomik Konularla İlgili Karar Verme Sürecine Katılımı: Polatlı Örneği”, Gazi Üniversitesi Endüstriyel Sanatlar Ĕgitim Fakültesi Dergisi, 26: 57-65.

Bokemeier, J. Garkovich, L.,(1987). “Assessing the Influence of Farm Women’s Self-Identity on Task Allocation and Decision Making”. Rural Sociology, 52(1): 13-36.

Bubolz, M.M. (2001). Family as source, user and builder of social capital. Journal of socio economics 30:129-131.

Demir, S. (2002). “Kırsal kalkınmada kadınlar orman köyü kalkınma kooperatifleri yönetici ve üyelerinin orman ekosistemlerindeki biyolojik çeşitliliği yerinde koruma eğitim projesi”, Ankara.

Doğanay, F. (1993). “Türkiye'de kadın girişimciliğini özendirme ve destekleme konusunda görüşler ve öneriler” Kadını Girişimciliğe Özendirme Ve Destekleme Paneli (Bildiriler Ve Tartışmalar), Sf:84-86. T.C. Başbakanlık Kssgm Eğitim Serisi, Yayın No: 74. Ankara.

Fazlığlu, A (2001). GAP’ta çok amaçlı toplum merkezleri (GAP-ÇATOM), toplum kalkınması hizmetlerinde sektörlerarası işbirliği içinde, UNICEF ve SHÇEK Ortak Yay., Ankara.

Fazlıŏlu, A (2002). Kadının kırsal kalkınmadaki yeri: GAP örneği, Atatürk Üniversitesi Ziraat Fakültesi Tarım Ekonomisi Bölümü ve Tarım Ekonomisi Derneği, 5. Tarım Ekonomisi Kongresi, Erzurum. www.gap.gov.tr (erişim tarihi, 21/07/2012).

Fazlığlu A, Gülçubuk, B. (2003). Türkiye'de ve GAP bölgesinde kadının statüsü ve toplumsal ilişkiler sistemindeki yeri, 6. Avrupa Sosyoloji Kongresi İspanya/Murcia www.gap.gov.tr (erişim tarihi, 30/07/2017).

Hablemitoğlu, Ş. (2001). Kırsal kesimde kadınların güçlenmesi ve “bilgi” arasındaki ilişki. Çiftçi Ve Köy Dünyası, 16 (203): 17-19.

Kulak,E., (2011). “Tarımsal üretim süreçlerindeki değişimin kırsal alanda kadın istihdamına etkileri: 1980 sonrası gelişmeler”. (Başbakanlık Kadının Statüsü Genel Müdürlüğü Uzmanlık Tezi), Ankara.

Malhotra N.K. (1993). Marketing research: An applied orientation, Prentice-Hall

Malhotra, N.K. (1999). Marketing Research, Prentice-Hall International, New Jersey, 864p.

Merter, F. (1990), 1950-1988 yılları arasında köy ailesinde meydana gelen değişmeler: Malatya örneği. Aile Araştırma Kurumu Yayınları, Ankara.

Mülayim, EAÜ (1999). Konya bölgesinde kırsal alanda tarımsal üretimde kadının yeri ve önemi. (Yüksek Lisans Tezi), Selçuk Üniversitesi Fen Bilimleri Enstitüsü, Konya.

Mülayim, Z.G.,(1992). “Atatürk’ten Bugüne Kooperatifçilik”, Yetkin Yayınları, Ankara.

Oğuz C.: (1992). "Konya ili tarım işletmelerinin hayvancılık şubelerinde kadın işgücü kullanma kapasitesinin saptanması üzerine bir araştırma", S.Ü. Ziraat Fakültesi Dergisi, say1:4, Konya.

Oğuz,C., Kan,A., (2010). “Kırsal Alanda Kadın Yoksulluğu:Yaylacık Köyü Örneği”. Türkiye Ix.Tarım Ekonomisi Kongresi, S:427-435,Urfa.

Özçatalbaş, O., (2001).“Adana İlinin Sosyo-Ekonomik Özellikleri Farklı İki Köyünde Kadınların Tarımsal Faaliyetlere Katılımı ve Yayımdan Yararlanma Olanakları”. Akdeniz Üniversitesi Ziraat Fakültesi Dergisi, 14/1, 79-88,Antalya

Özdemir, G., Unakıtan, G., Keskin, G., Yılmaz, E., Er Ülker, F., (2017). “Tarım İşletmelerinde Kadınların Yarattığı İș Gücü Değeri Ve Örgütlenme Yaklaşımları: Trakya Bölgesi Örneği’’ Sosyal Politika Çalışmaları Dergisi Yıl: 17 Sayı: 39 Tarih: Temmuz-Aralık 2017 Ss: 33-58 Issn: 2148-9424

Özdemir, G., Unakıtan, G., Keskin, G., Yılmaz, E., Er Ülker, F., (2015). Tarım işletmelerinde alternatif gelir sağlama olanaklarına kadınların bakış açısı ve örgütlenme durumlarının belirlenmesi Trakya bölgesi araştırması, DÜNYA BANKASI Destekli Proje.

Özdemir, G., (2013). Women's Cooperatives in Turkey” (Orijinal Research Article), Procedia- Social and Behavioral Sciences, vol. 81, pp. 300-305, 2013.

Özer,D. Taluğ,C., (2008). “Yeniden yerleşimin hayvancılıkla uğraşan kırsal hanelerde kadının toplumsal cinsiyet rollerine etkisi”. Harran Üniv. Ziraat Fakültesi Dergisi, 12 (2):1-9,Urfa.

Özgen, Ö. Ufuk, H. (2011). “Kırsal kesimde kadın eğitimi”, http://www.zmo.org.tr/resimler/ekler/6121d1f782d29b6_ek.pdf?tipi=14\&sube (Erişim: 14.11.2017): 1063-1078.

Özkan,B.,(2000).“Antalya ilinde sera sebzeciliğinde kadın üreticilerin rolü”, Akdeniz Üniversitesi Ziraat Fakültesi Dergisi, Cilt: 13 (2): 133 143

Rosenfeld, R.A., (1986). U.S. "Farm women: their part in farm work and decision making". Work And Occupations, 13(2): 179-202.

Yıldırak, N.,Gülçubuk, B.,Gün S.,Olhan, E., Kılıç, M., (2003), “Türkiye’de gezici ve geçici kadın tarım işçilerinin çalışma ve yaşam koşulları ve sorunları", Tarım-İş, Ankara.

Yılmaz, H., Gül, A. (2010).“Adana ilinde kooperatifler aracılığıyla uygulanan süt sığırcılığı projelerinin genel bir değerlendirilmesi”. Türkiye IX.Tarım Ekonomisi Kongresi, sayfa 534-541,Şanlıurfa.

Yumuşak, İ. G. (2003), “Kadın eğitiminin ekonomik boyutu, II. Ulusal Bilgi, Ekonomi ve Yönetim Kongresi, Derbent. 